for

\title{
Perylenedianhydride-based Polyimides as Organic Cathodes for Rechargeable Lithium and Sodium Batteries
}

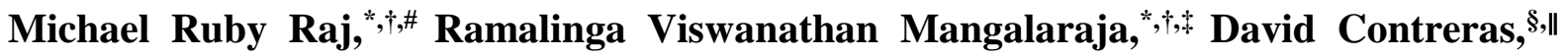 \\ Kokkarachedu Varaprasad, ${ }^{\perp}$ Mogalahalli Venkatashamy Reddy, $\#, \|, \bullet$ and Stefan Adams ${ }^{\text {II }}$ \\ †Department of Materials Engineering, Faculty of Engineering, University of Concepción, Concepción-4070409, \\ Chile. \\ †Technological Development Unit (UDT), University of Concepcion, Coronel Industrial Park, Coronel 4191996, \\ Chile.
}

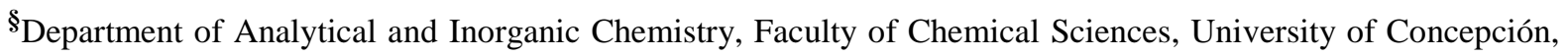
Concepción-4070409, Chile.

"Centre for Biotechnology, University of Concepción, Concepción-4070409, Chile.

${ }^{\perp}$ Centro de Investigaciónde Polímeros Avanzados (CIPA), Avenida Collao 1202, Edificio de Laboratorio CIPA, Concepción 00043, Chile

\#Department of Physics and ${ }^{\mathrm{II}}$ Department of Materials Science and Engineering, Faculty of Engineering, National University of Singapore, 117576.

- Centre of Excellence in Transportation Electrification and Energy Storage (CETEES), Hydro-Québec, 1806, Lionel-Boulet blvd., Varennes, Qc, J3X 1S1, Canada.

*Corresponding authors E-mails: rubyraj06@gmail.com (M. Ruby Raj), mangal@udec.cl (R.V. Mangalaraja).

\section{$\underline{\text { Contents }}$}

1. Experimental section

1.1. Material synthesis

1.2. Materials Characterization

1.3. Electrochemical Measurements

2. Synthetic procedure for the synthesis of PTCDA-based polyimides through polymerization of non-bay-substituted PTCDA with bifunctional amine compounds.

2.1. Synthesis of PDI-Bz 
Figure S1. FT-IR spectra of (a) PTCDA, PDI-Bz and PDI-Ur (KBr pellets); (b) Extended spectrum for PTCDA, PDI-Bz and PDI-Ur.

Figure S2. Thermogravimetric analysis curves of (a) PTCDA; (b) PDI-Bz and (c) PDI-Ur with a heating rate of $10^{\circ} \mathrm{C} / \mathrm{min}$ under $\mathrm{N}_{2}$.

Figure S3. The high-resolution regional XPS spectra of C 1 s orbital of (a) PDI-Bz and (d) PDI-Ur; the XPS spectra of N 1 s orbital of (b) PDI-Bz and (e) PDI-Ur and the XPS spectra of O 1 s orbital of (c) PDI-Bz and (f) PDI-Ur.

Figure S4. Raman spectra for PDI-Bz and PDI-Ur under $\lambda=512 \mathrm{~nm}$ excitation under $\mathrm{N}_{2}$ atmosphere.

Figure S5. Powder X-ray diffraction patterns of PDI-Bz and PDI-Ur.

Figure S6. Field-Emission Scanning Electron Microscopic images of PDI-Bz and PDI-Ur.

Figure S7. Typical SEM images for PDI-Ur vs. $\mathrm{Na}^{+} / \mathrm{Na}$ after $1^{\text {st }}$ charged at a current density of $25 \mathrm{~mA} / \mathrm{g}$. The SEM images ( $\mathrm{a} \& \mathrm{~b}$ ) show the formation of $\mathrm{Na}^{+}$ion dendrites.

Figure S8. Differential capacity $(\mathrm{dQ} / \mathrm{dV})$ vs. voltage plot for PDI-Ur $\left(\mathrm{vs} . \mathrm{Na}^{+} / \mathrm{Na}\right)$ based cell at the current density of $25 \mathrm{~mA} / \mathrm{g}$.

Figure S9. Typical SEM images for (a) PDI-Bz vs. $\mathrm{Li}^{+} / \mathrm{Li}$, (b) PDI-Bz vs. $\mathrm{Na}^{+} / \mathrm{Na}$, (c) PDIUr vs. $\mathrm{Li}^{+} / \mathrm{Li}$ and (d) PDI-Ur vs. $\mathrm{Na}^{+} / \mathrm{Na}$ after 25 cycled at a current density of $25 \mathrm{~mA} / \mathrm{g}$. SEM images confirmed that the formation of thick solid electrolyte interface (SEI) layer in PDI-Bz (vs. $\mathrm{Li}^{+} / \mathrm{Li}$ ) and PDI-Ur (vs. $\mathrm{Li}^{+} / \mathrm{Li}$ ) compared to their $\mathrm{Na}^{+} / \mathrm{Na}$ upon charging/discharging cycles.

Figure S10. Coulombic efficiency profiles of (a) PDI-Bz vs. $\mathrm{Li}^{+} / \mathrm{Li}$, (b) PDI-Bz vs. $\mathrm{Na}^{+} / \mathrm{Na}$, (c) PDI-Ur vs. $\mathrm{Li}^{+} / \mathrm{Li}$ and (d) PDI-Ur vs. $\mathrm{Na}^{+} / \mathrm{Na}$ during 50 cycling at a current density of $25 \mathrm{~mA} / \mathrm{g}$.

Figure S11. The Nyquist plots for (a) PDI-Bz vs. $\mathrm{Li}^{+} / \mathrm{Li}$, (b) PDI-Bz vs. $\mathrm{Na}^{+} / \mathrm{Na}$, (c) PDI-Ur vs. $\mathrm{Li}^{+} / \mathrm{Li}$ and (d) PDI-Ur vs. $\mathrm{Na}^{+} / \mathrm{Na}$ before and after 50 cycled battery cells at a current density of $25 \mathrm{~mA} / \mathrm{g}$. The corresponding equivalent circuits of PDI-Bz and PDI-Ur battery cells.

Table S1. The calculated theoretical capacities of PDI-Bz and PDI-Ur and their electrogenerated species.

Table S2. Comparison of the performance of PDI-Bz and PDI-Ur $\left(\mathrm{vs} \mathrm{Li}^{+} / \mathrm{Li} \& \mathrm{Na}^{+} / \mathrm{Na}\right)$ with the state-of-the-art PDI-based materials reported in the literature. 


\section{Experimental Section}

\subsection{Material synthesis}

Synthetic methods for synthesis of perylenediimides (PDIs)-based polyimides (namely, perylenediimide-benzidine (PDI-Bz), and perylenediimide-urea (PDI-Ur)) through imidization of non-bay-substituted PTCDA unit using bifunctional amine compounds (i.e., benzidine, and carbonyl diamine (urea)). The fabrication of cathode electrodes using PDI-based polyimides could significantly influence the electrochemical performance of metal-ion batteries with good cycling performances. The detailed synthetic procedures and characterization by standard spectroscopic techniques for synthesized polyimides were provided in the supporting information. The perylene polyimides studied in this work were synthesized by following procedures shown in Scheme 1.

\subsection{Materials Characterization.}

The prepared PDI-Bz and PDI-Ur were initially characterized by using Fourier transform infrared spectroscopy (FTIR) on a Perkin Elmer, UATR two, FTIR spectrometer (Beaconsfield, Bucks, UK) with KBr pellets. Thermo gravimetric analysis (TGA) was performed using a TGA Q 50 thermal analyzer (T.A. instruments-water LLC, Newcastle, DE, USA) at a heating rate of $10{ }^{\circ} \mathrm{C} / \mathrm{min}$ ramp from 50 to $800{ }^{\circ} \mathrm{C}$ under a nitrogen atmosphere. The solution ${ }^{1} \mathrm{H}-\mathrm{NMR}$ spectra were recorded on a Bruker Avance $400(400 \mathrm{MHz})$ spectrometer in both deuterated chloroform $\left(\mathrm{CDCl}_{3}\right)$ and dimethyl sulfoxide (DMSO-d $\left.\mathrm{d}_{6}\right)$ solution at $298 \mathrm{~K}$, unless specified otherwise. A solid state ${ }^{13} \mathrm{C}$-MAS NMR measurements were performed on a Bruker Avance $400(400 \mathrm{MHz})$ spectrometer with a MAS rate of $5 \mathrm{kHz}$. Elemental analysis was performed using a Vario EL III elemental analyzer. The polyimides were structurally characterized by the powder XRD technique (Bruker D8 Advance) using a $\mathrm{Cu} \mathrm{K \alpha}$ radiation source. The morphological characterization of the samples has been carried out using SEM (JEOL-JSM 6390) and TEM (JEOL JEM-3010; $300 \mathrm{kV}$ ) analysis.

\subsection{Electrochemical Measurements}

All organic cathodes were obtained by mixing of the active material (PDI-Bz and PDIUr), conductive carbon black (ENSACO, MMM Super P, $230 \mathrm{~m}^{2} / \mathrm{g}$ ), and a polymer binder (Kynar 2801, Polyvinylidene difluoride (PVDF)) in N-methylpyrrolidone (NMP) as a solvent at the weight ratio of 60:30:10 to form well-dispersed slurry. The resulting slurry was uniformly spread over etched an aluminium foil (Shenzhen Vanlead Tech. Co. Ltd, China, as a current 
collector) at a thickness of $20 \mu \mathrm{m}$ by using doctor blade technique and then the coated aluminium foil was dried immediately in a blast oven at $100{ }^{\circ} \mathrm{C}$ for $12 \mathrm{~h}$ to produce electrode films. In order to increase the contact between the polyimide material and the aluminium foil, a twin roller machine is used to press the coated aluminium foil into a sheet. Finally, the electrode cutter was used to punch the sheet into small circular discs with a diameter of 12 $\mathrm{mm} / 1 \mathrm{~cm}$ and the mass of the active material coated on the current collector is $2.0 \pm 0.3 \mathrm{mg} \mathrm{cm}^{-}$ 2. After weighing the electrode discs, the electrodes were fabricated into half-cell lithium batteries using CR2016 (3.6V) type of coin cell assembly with pure lithium foil was used as a counter electrode and $1 \mathrm{M} \mathrm{LiPF}_{6}$ in a mixture of ethylene carbonate (EC)/dimethylcarbonate (DMC) (EC/DMC; 1:1 molar ratio) was used as the electrolyte in an argon-filled glove box with the moisture and oxygen/water levels below $1 \mathrm{ppm}$. The battery cells were assembled and placed for approximately $12 \mathrm{~h}$ at room temperature. The electrochemical characterization of the polyimides as the cathodes in sodium-ion (SIBs) batteries were also evaluated in a similar way as the aforementioned lithium battery tests, but we have used sodium foil as counter electrode, glass fiber as a separator, EC/DMC (1:1 molar ratio) solution of $\mathrm{NaClO}_{4}$ as an electrolyte. Then the galvanostatic charge and discharge measurements were performed on the fabricated battery cells by using a Bitrode multi-channel battery tester (model, MCV16-0.5, USA). The current rates for galvanostatic measurements were calculated based on the theoretical specific capacity of polyimides. Cyclic voltammetry was performed at a scan rate of $0.1 \mathrm{mVs}^{-1}$ in a voltage range between $1.5-3.5 \mathrm{~V}$ versus $\mathrm{Li}^{+} / \mathrm{Li}\left(1.2-3.5 \mathrm{~V}\right.$ versus $\left.\mathrm{Na}^{+} / \mathrm{Na}\right)$ by using the Solatron, 1470 battery test unit. The electrochemical impedance spectroscopy (EIS) was also recorded on the Solartron impedance/gainphase analyzer (model SI 1255) coupled with a potentiostat (SI 1268). The frequency was varied from 0.1 to $100000 \mathrm{~Hz}$ (or $0.003 \mathrm{~Hz}$ to $350,000 \mathrm{~Hz}$ ) with alternating current signal amplitude of $10 \mathrm{mV}$. 
Scheme S1. Synthetic methods for synthesis of PTCDA-based polyimides (namely, perylenediimide-benzidine (PDI-Bz), and perylenediimide-urea (PDI-Ur)) through imidization of non-bay-substituted PTCDA unit using bifunctional amine compounds (i.e., benzidine, and carbonyl diamine (urea)).

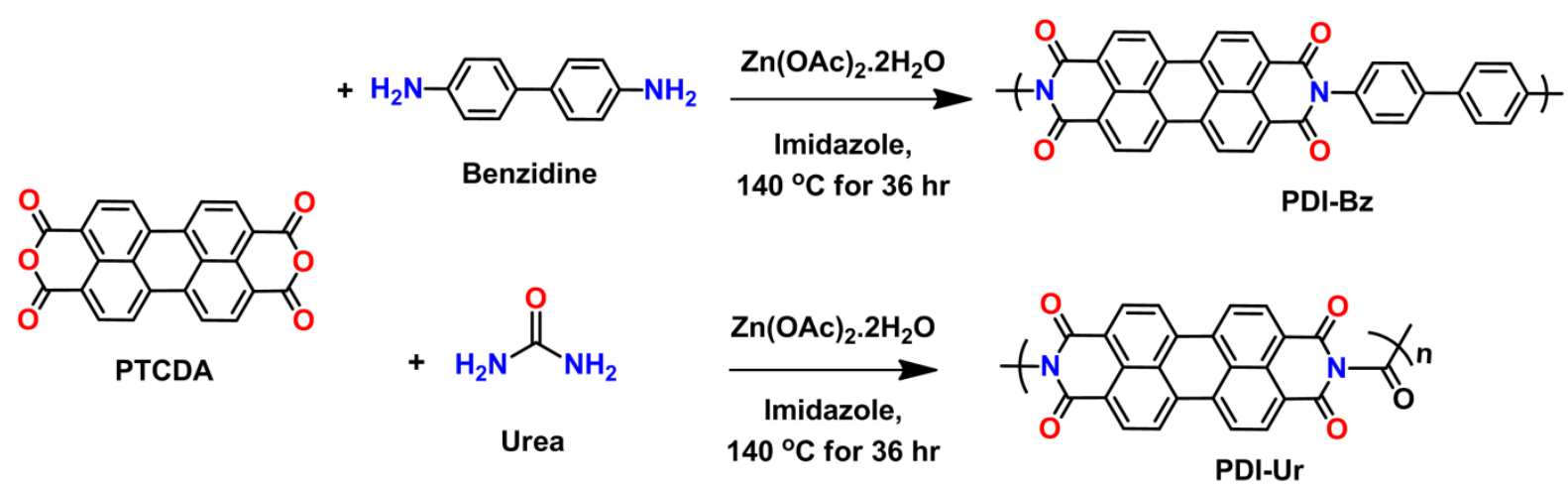

Scheme S2. A representative scheme of PDI-Bz and PDI-Ur-based cathode materials indicating of their redox reaction mechanism of insertion/de-insertion of metal during cyclic voltammetry (one-step reaction of two electrons is equally applicable for PDI-Bz and of three electrons is equally applicable for PDI-Ur) and galvanostatic charge/discharge cycling and fast multiple reaction kinetics with metal-ions. PDI-Ur has an additional carbonyl group in imide region that involving reversibly exchange one electron from oxygen atom with metal-ion. A positively charged $\mathrm{N}^{+}$at imide position could interact with one $\mathrm{PF}^{-}$to form a stable compound, which absorbs $\mathrm{PF}^{-}$from the electrolytes and then one $\mathrm{PF}^{-}$could be released and dissolved again into the electrolyte during charge/discharge process. The calculated theoretical capacity $\left(\mathrm{C}_{\text {theor }}\right)$ for PDI-Bz and PDI-Ur and its electrogenerated species in each step.

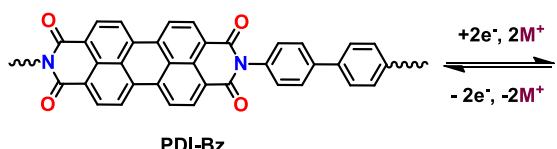

PDI-Bz

where $\mathrm{M}^{+}=\mathrm{Li}^{+}$and $\mathrm{Na}^{+}$

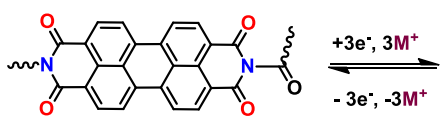

PDI-Ur

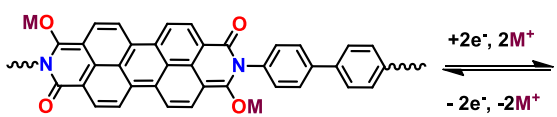

PDI-Bz ${ }^{2-} \mathrm{M}^{+}$

$C_{\text {theor }}, \mathrm{mAh} / \mathrm{g}=99$

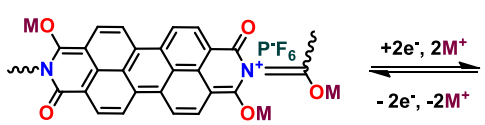

PDI-Ur ${ }^{3-} \mathrm{M}^{+}$

$C_{\text {theor }}, \mathrm{mAh} / \mathrm{g}=186$

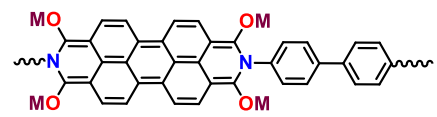

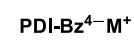

$C_{\text {theor }}, \mathrm{mAh} / \mathrm{g}=197.7$

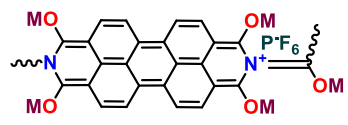

PDI-Ur ${ }^{5-} \mathbf{M}^{+}$

$\mathrm{C}_{\text {theor }}, \mathrm{mAh} / \mathrm{g}=\mathbf{3 1 0}$ 
2. Synthetic procedure for the synthesis of PTCDA-based polyimides through polymerization of non-bay-substituted PTCDA with bifunctional amine compounds:

2.1. Synthesis of PDI-Bz: The mixture of PTCDA ( $1 \mathrm{~g}, 2.55 \mathrm{mmol})$, benzidine $(0.5 \mathrm{~g}, 1.27$ $\mathrm{mmol}), 5 \mathrm{~g}$ of imidazole and zinc acetate $(0.55 \mathrm{~g}, 2.99 \mathrm{mmol})$ was heated with stirring at $140{ }^{\circ} \mathrm{C}$ for $36 \mathrm{~h}$. After cooled to room temperature, the reaction mixture was poured into $1 \mathrm{~N}$ hydrochloric acid $(25 \mathrm{~mL})$ and stirred for $15 \mathrm{~min}$ for product precipitation. The resulting precipitate was collected through vacuum filtration and washed with boiling saturated potassium carbonate solution followed by distilled water for three times and dried at $100{ }^{\circ} \mathrm{C}$ in open air. Then, resulting dried product was washed several times with DMSO until the washings became colorless to remove the short oligomers from the mixture. Final product was collected as dark red powder $(1.2 \mathrm{~g}, 87 \%)$. Decomposition temperature based on $5 \%$ weight loss by TGA: $517{ }^{\circ} \mathrm{C}$; Solid state ${ }^{13} \mathrm{C}$ MAS NMR (100 MHz, $\delta$ ): 175.65 (C=O), 142.79 (Ar-C), 132.99 (Ar-C), 115.97 (Ar-C). IR (KBr): v = 1770 (s), 1755 (s), 1731 (s), 1698 (s), 1660 (s), 1593 (s), 1432 (s), 1406 (s), 1359 (s), 1300 (s), $1235 \mathrm{~cm}^{-1}$ (s). Anal. calcd. for $\left(\mathrm{C}_{36} \mathrm{H}_{17} \mathrm{~N}_{2} \mathrm{O}_{4}\right)_{\mathrm{n}}$ : C, 79.84; H, 3.16; N, 5.17; found: C, 79.21; H, 2.96; N, $4.90 \%$.

2.2. Synthesis of PDI-Ur: This compound was synthesized according to similar procedures the above procedures. Briefly, a mixture of PTCDA ( $1 \mathrm{~g}, 2.55 \mathrm{mmol})$, Urea (Carbonyl diamine, $0.15 \mathrm{~g}, 2.55 \mathrm{mmol}), 5 \mathrm{~g}$ of imidazole and zinc acetate $(0.47 \mathrm{~g}, 2.56 \mathrm{mmol})$ was heated with stirring at $140{ }^{\circ} \mathrm{C}$ for $36 \mathrm{~h}$. After cooled to room temperature, the reaction mixture was poured into $1 \mathrm{~N}$ hydrochloric acid $(25 \mathrm{~mL})$ and stirred for $15 \mathrm{~min}$ for product precipitation. The resulting precipitate was collected through vacuum filtration and washed with boiling saturated potassium carbonate solution followed by distilled water for three times and dried at $100{ }^{\circ} \mathrm{C}$ in open air. Then, resulting dried product was washed several times with DMSO until the washings became colorless to remove the short oligomers from the mixture. Final product was collected as dark red powder $(0.64 \mathrm{~g}, 58 \%)$. Decomposition temperature based on $5 \%$ weight loss by TGA: $420{ }^{\circ} \mathrm{C}$; Solid state ${ }^{13} \mathrm{C}$ MAS NMR (100 MHz, $\delta$ ): 175.66 (C=O), 142.60 (Ar-C), 132.99 (Ar-C), 115.99 (Ar-C). IR (KBr): v = 1755 (s), 1716 (s), 1684 (s), 1590 (s), 1431 (s), 1400 (s), 1361 (s), 1323(s), $1275 \mathrm{~cm}^{-1}$ (s). Anal. calcd. for $\left(\mathrm{C}_{25} \mathrm{H}_{8} \mathrm{~N}_{2} \mathrm{O}_{5}\right)_{\mathrm{n}}: \mathrm{C} 71.77, \mathrm{H} \mathrm{2.41,} \mathrm{N}$ 6.70\%; found: C 71.14, H 2.61, N 6.46\%. 
Figure S1. FT-IR spectra of (a) PTCDA, PDI-Bz and PDI-Ur (KBr pellets); (b) Extended spectrum for PTCDA, PDI-Bz and PDI-Ur.
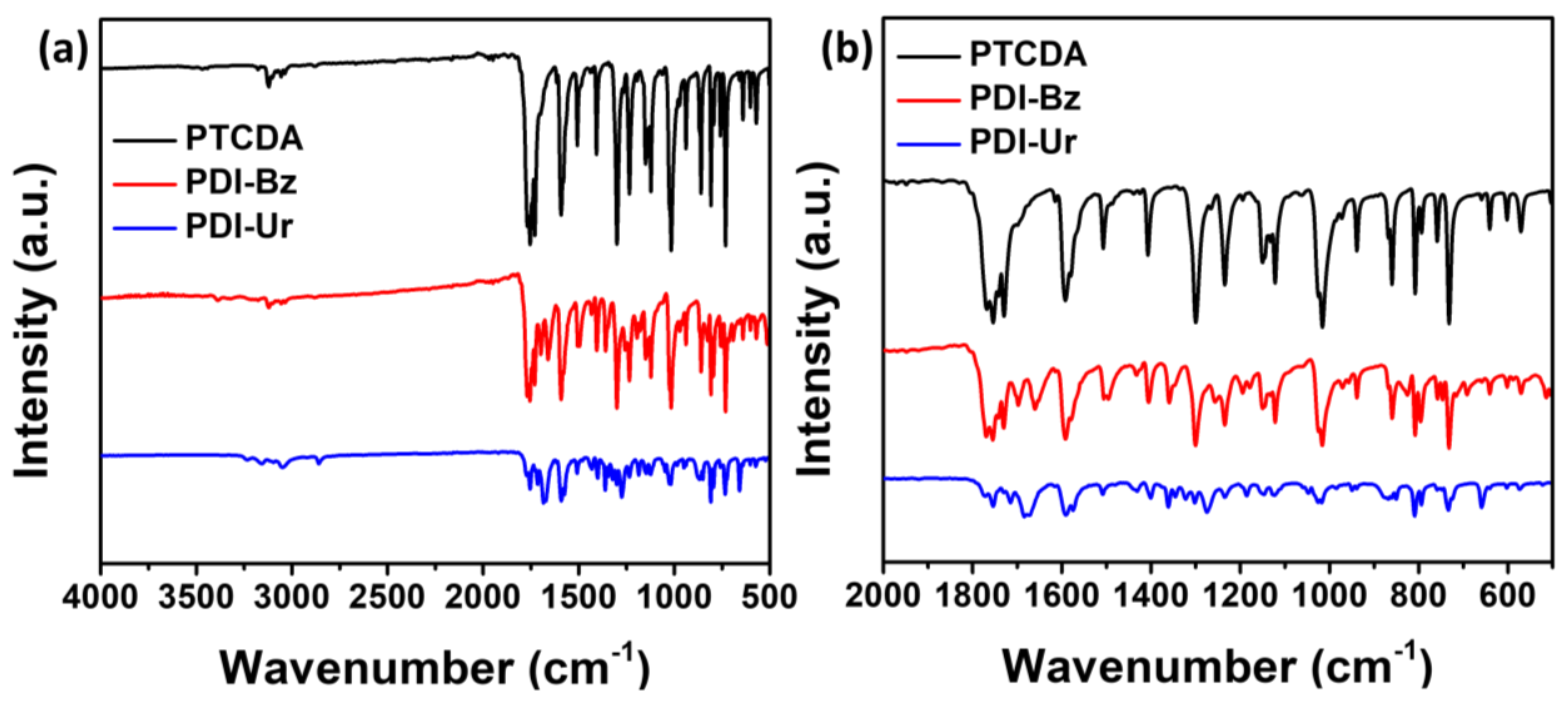

Figure S2. Thermogravimetric analysis curves of (a) PTCDA; (b) PDI-Bz and (c) PDI-Ur with a heating rate of $10^{\circ} \mathrm{C} / \mathrm{min}$ under $\mathrm{N}_{2}$ and their corresponding derivative weight change curves.
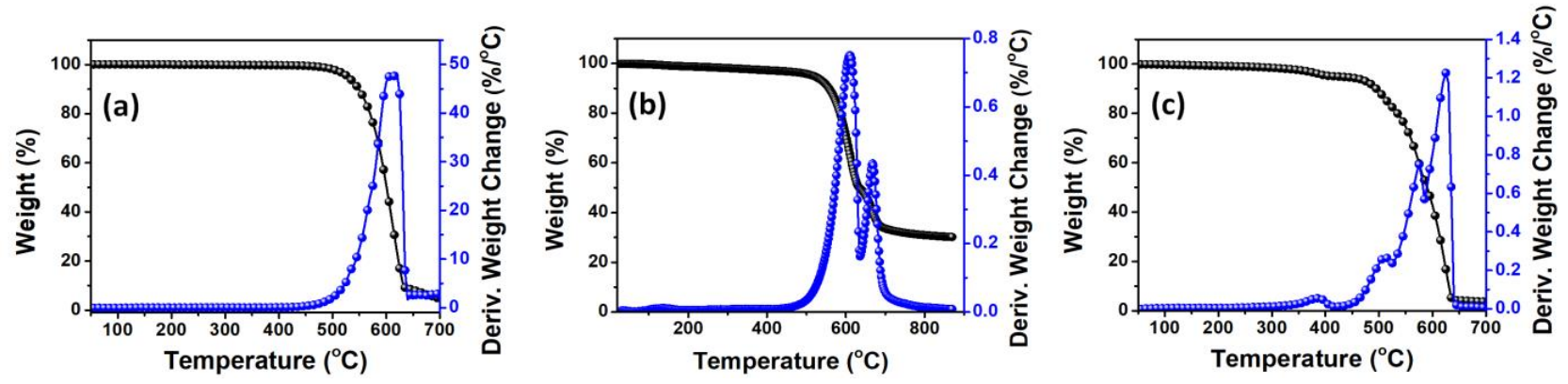
Figure S3. The high-resolution regional XPS spectra of C 1 s orbital of (a) PDI-Bz and (d) PDI-Ur; the XPS spectra of N 1 s orbital of (b) PDI-Bz and (e) PDI-Ur and the XPS spectra of O 1 s orbital of (c) PDI-Bz and (f) PDI-Ur.
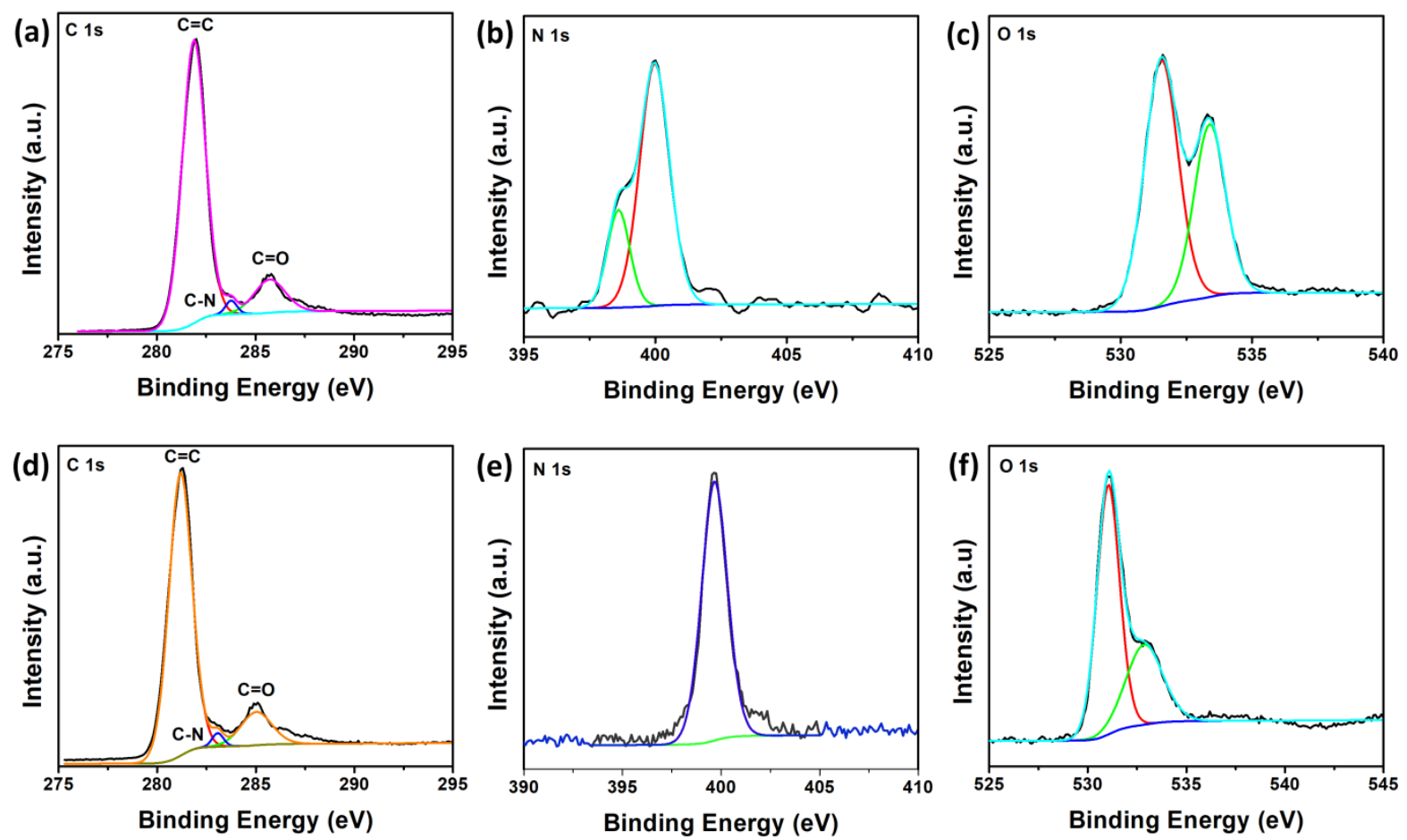
Figure S4. Raman spectra for PDI-Bz and PDI-Ur under $\lambda=512 \mathrm{~nm}$ excitation under $\mathrm{N}_{2}$ atmosphere.

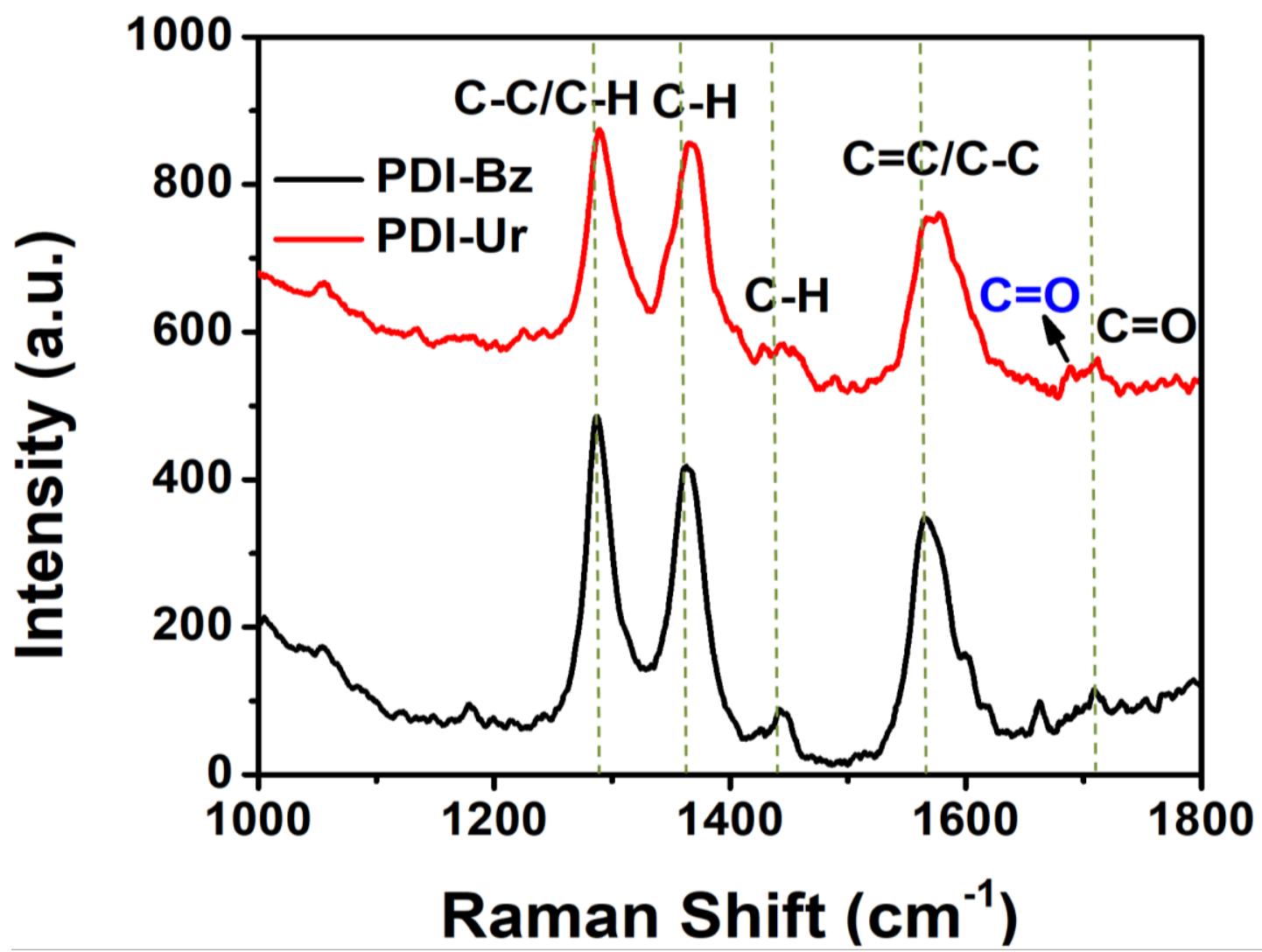


Figure S5. Powder X-ray diffraction patterns of PDI-Bz and PDI-Ur.

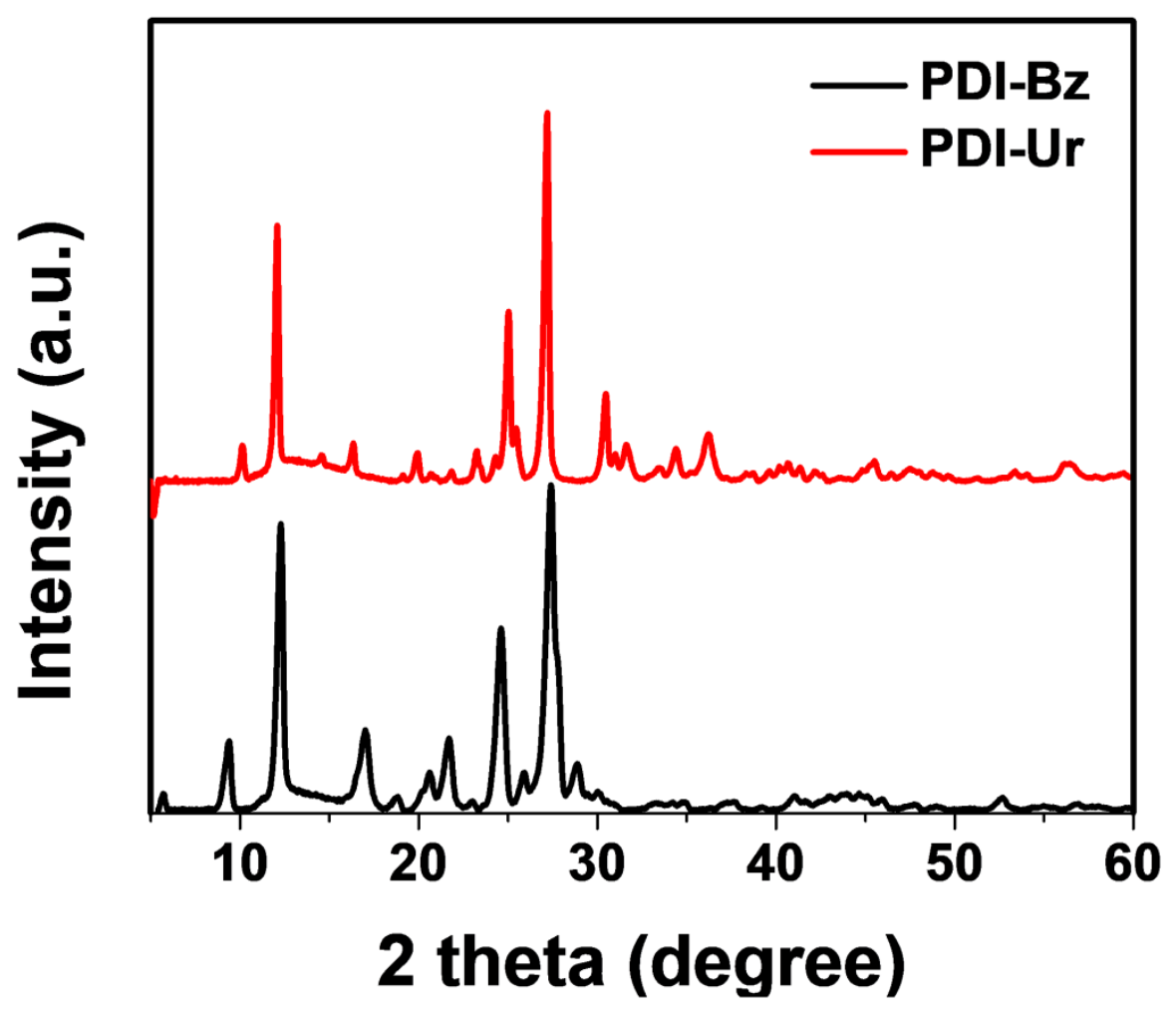

Figure S6. Field-Emission Scanning Electron Microscopic images of PDI-Bz and PDI-Ur.
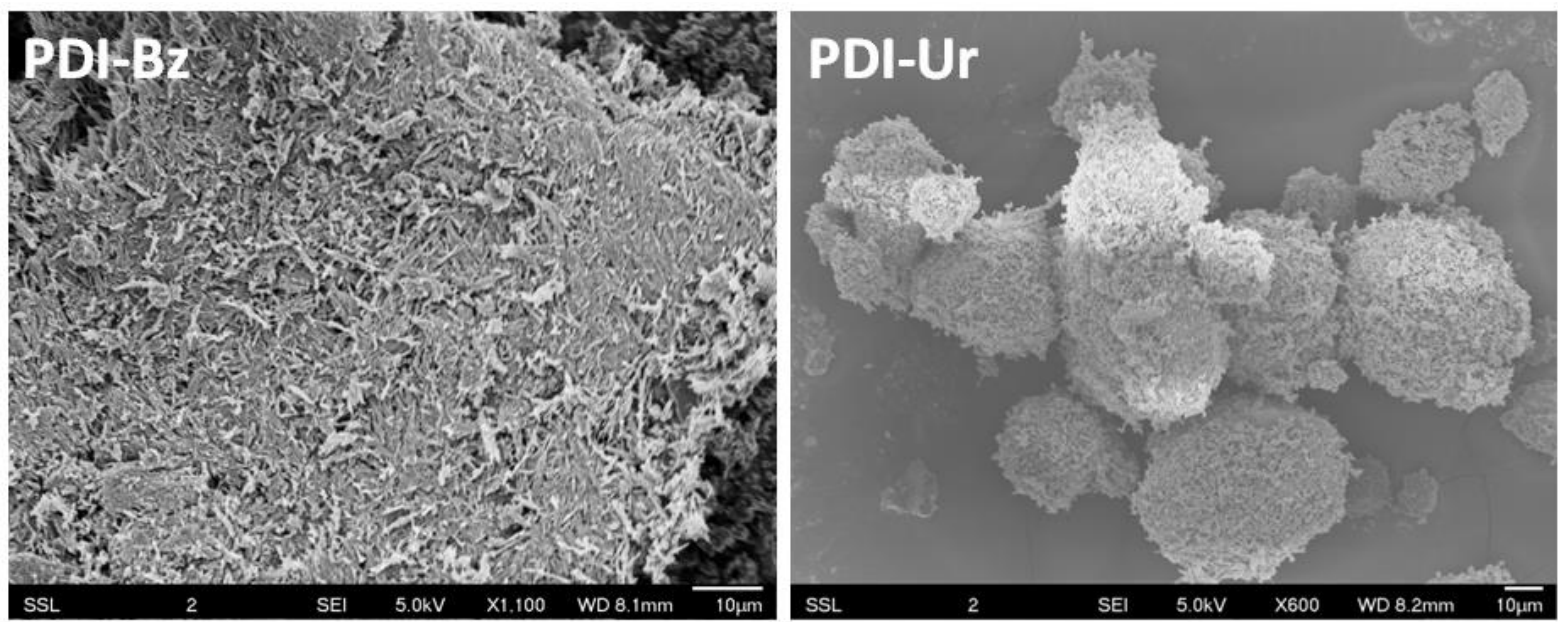
Figure S7. Typical SEM images for PDI-Ur vs. $\mathrm{Na}^{+} / \mathrm{Na}$ after $1^{\text {st }}$ charged at a current density of $25 \mathrm{~mA} / \mathrm{g}$. The SEM images ( $\&$ b) show the formation of $\mathrm{Na}^{+}$ion dendrites.
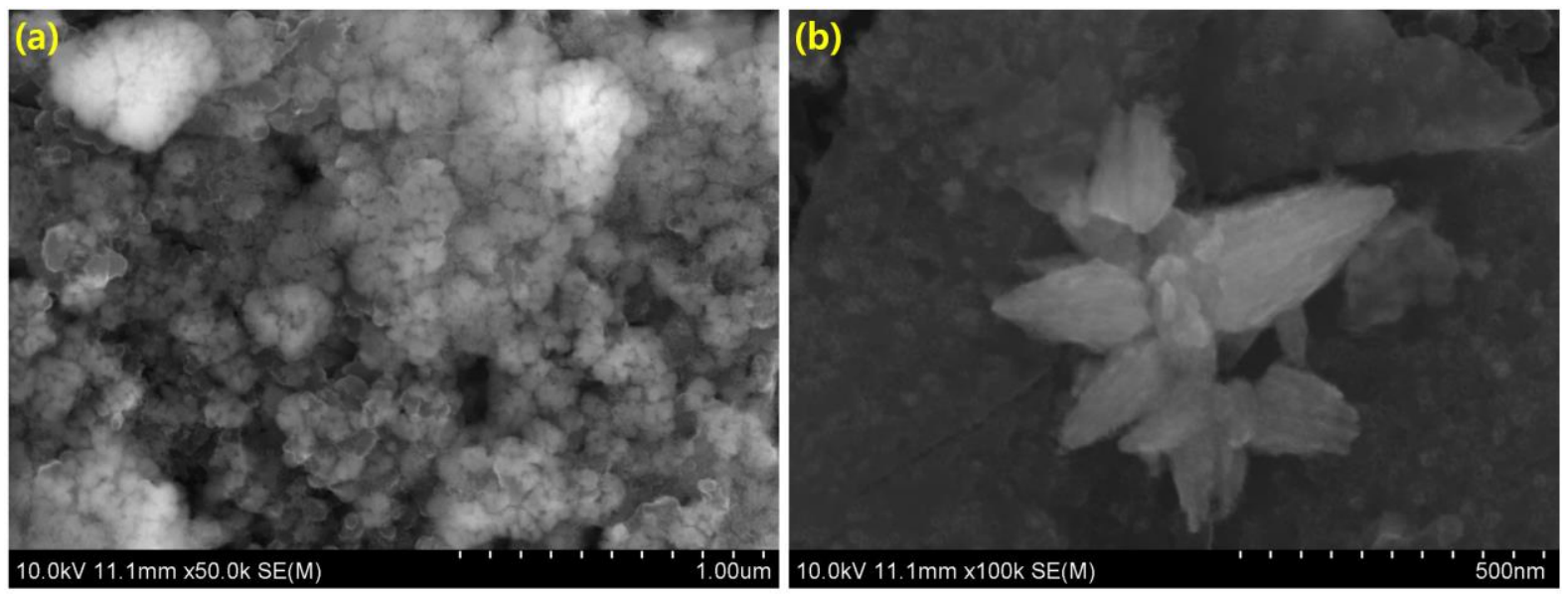

Figure S8. Differential capacity $(\mathrm{dQ} / \mathrm{dV})$ vs. voltage plot of PDI-Ur $\left(\mathrm{vs}\right.$. $\mathrm{Na}^{+} / \mathrm{Na}$ ) based cell at the current density of $25 \mathrm{~mA} / \mathrm{g}$.

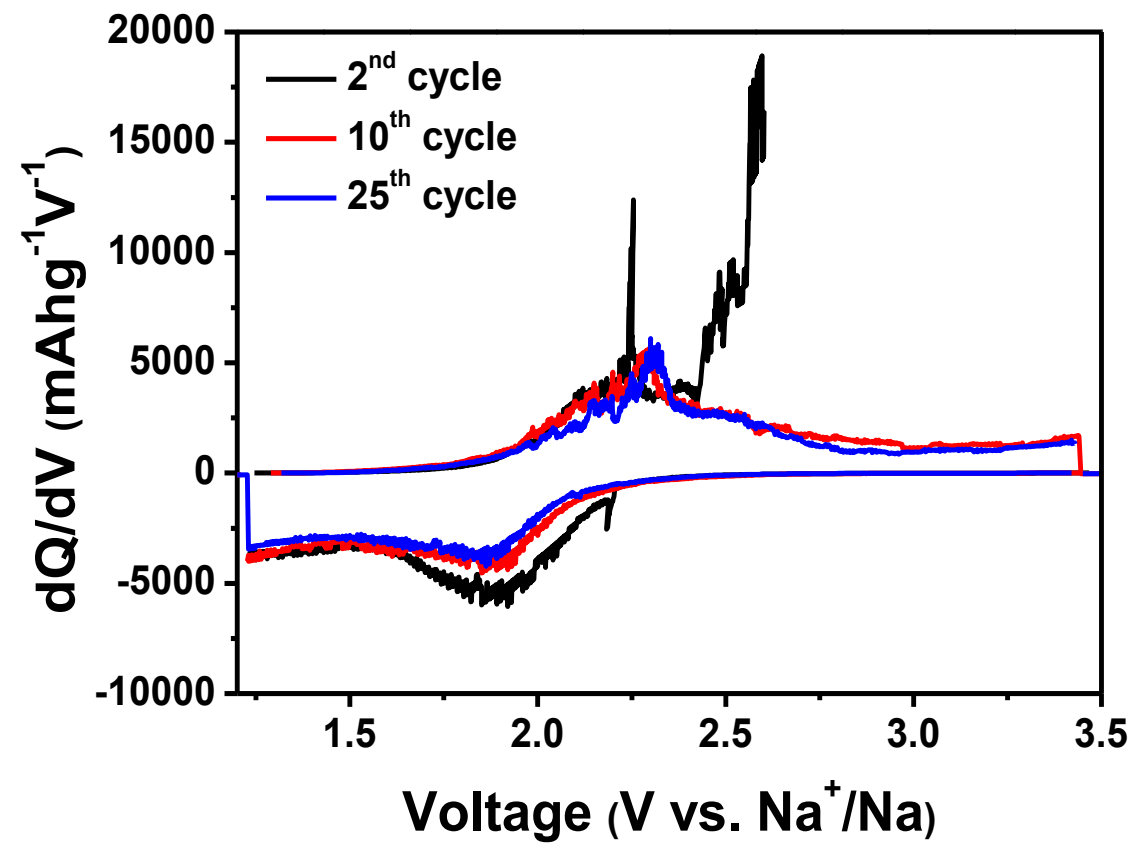


Figure S9. Typical SEM images for (a) PDI-Bz vs. $\mathrm{Li}^{+} / \mathrm{Li}$, (b) PDI-Bz vs. $\mathrm{Na}^{+} / \mathrm{Na}$, (c) PDIUr vs. $\mathrm{Li}^{+} / \mathrm{Li}$ and (d) PDI-Ur vs. $\mathrm{Na}^{+} / \mathrm{Na}$ after 25 cycled at a current density of $25 \mathrm{~mA} / \mathrm{g}$. SEM images confirmed that the formation of thick solid electrolyte interface (SEI) layer in PDI-Bz (vs. $\mathrm{Li}^{+} / \mathrm{Li}$ ) and PDI-Ur (vs. $\mathrm{Li}^{+} / \mathrm{Li}$ ) compared to their $\mathrm{Na}^{+} / \mathrm{Na}$ upon charging/discharging cycles.
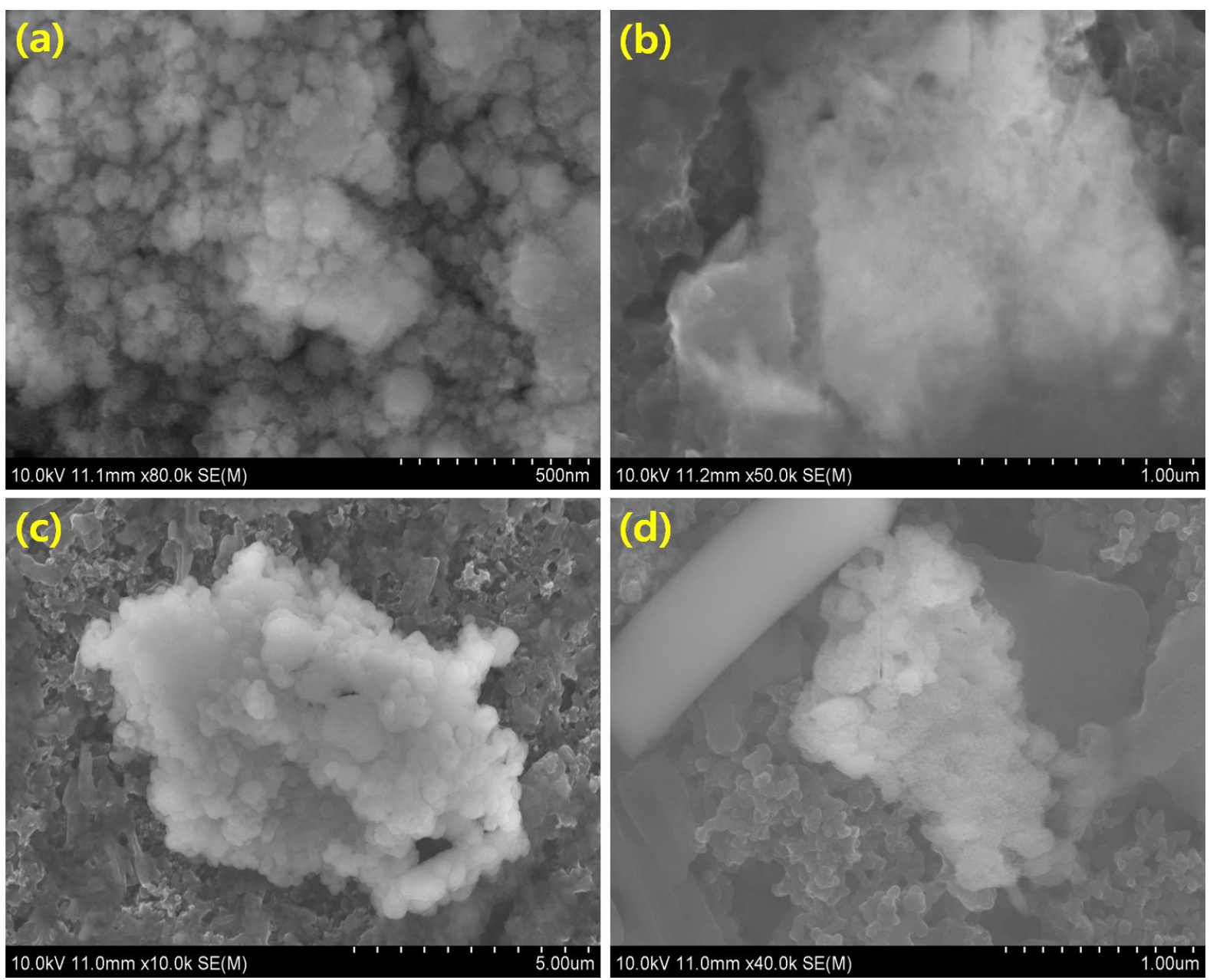
Figure S10. Coulombic efficiency profiles of (a) PDI-Bz vs. $\mathrm{Li}^{+} / \mathrm{Li}$, (b) PDI-Bz vs. $\mathrm{Na}^{+} / \mathrm{Na}$, (c) PDI-Ur vs. $\mathrm{Li}^{+} / \mathrm{Li}$ and (d) PDI-Ur vs. $\mathrm{Na}^{+} / \mathrm{Na}$ during 50 cycling at a current density of 25 $\mathrm{mA} / \mathrm{g}$.
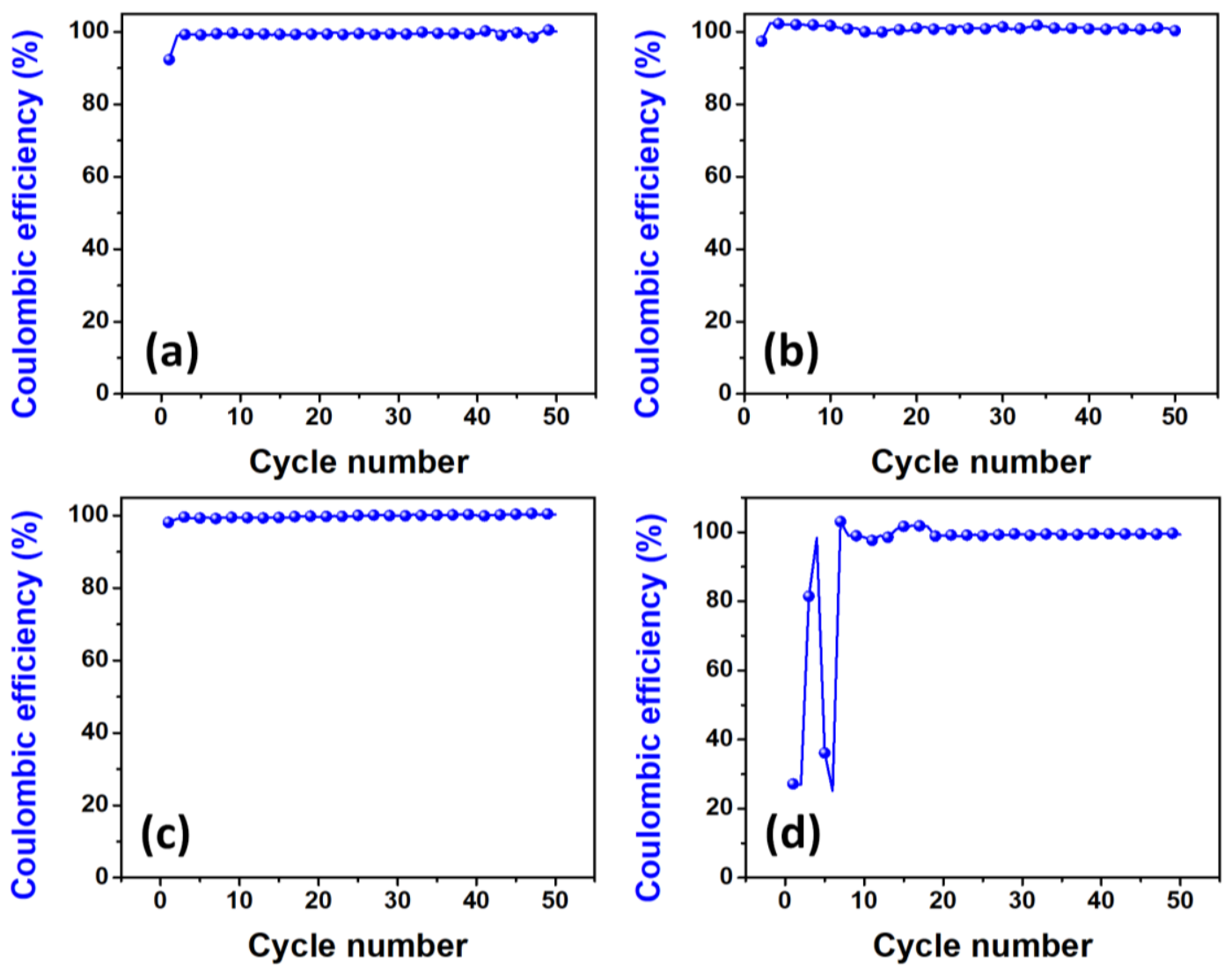
Figure S11. The Nyquist plots for (a) PDI-Bz vs. $\mathrm{Li}^{+} / \mathrm{Li}$, (b) PDI-Bz vs. $\mathrm{Na}^{+} / \mathrm{Na}$, (c) PDI-Ur vs. $\mathrm{Li}^{+} / \mathrm{Li}$ and (d) PDI-Ur vs. $\mathrm{Na}^{+} / \mathrm{Na}$ before and after 50 cycled battery cells at a current density of $25 \mathrm{~mA} / \mathrm{g}$. The corresponding equivalent circuits of PDI-Bz and PDI-Ur battery cells.
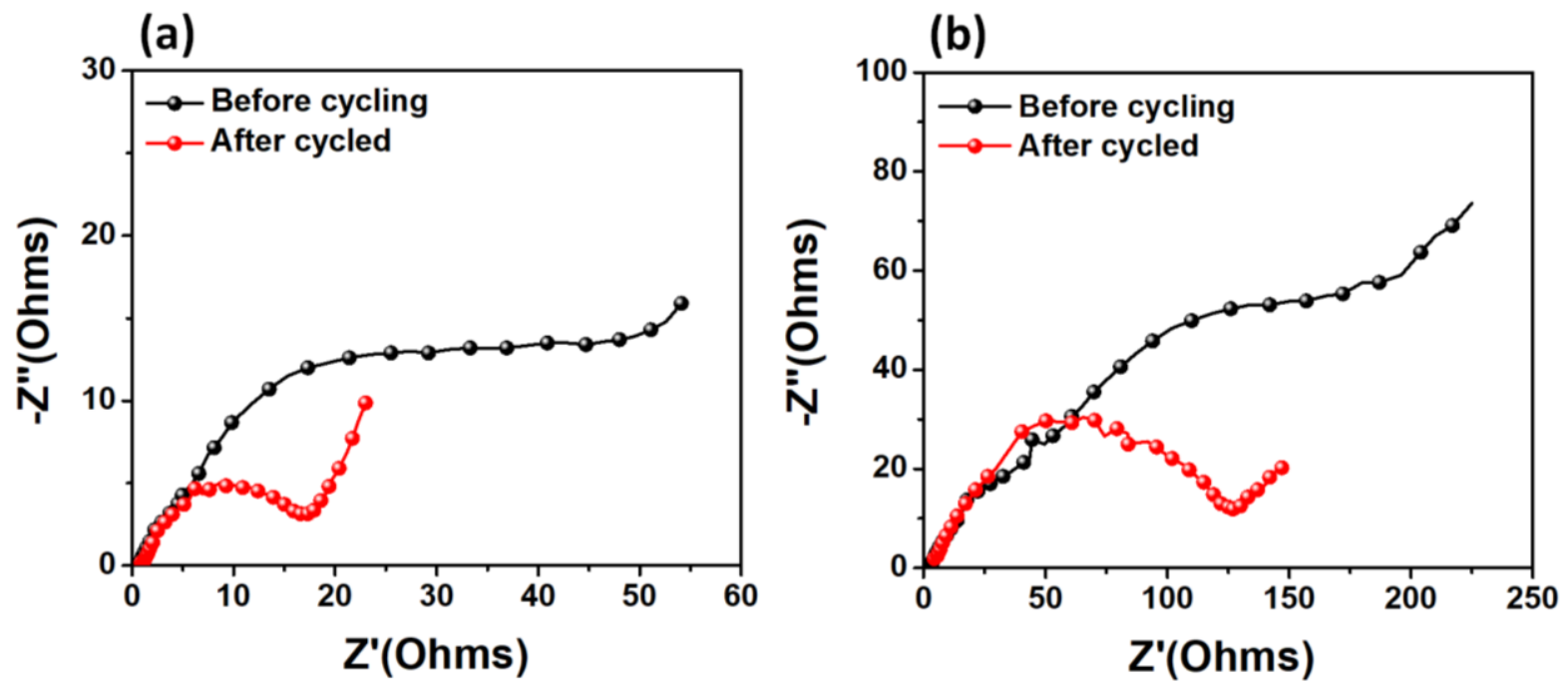

(c)

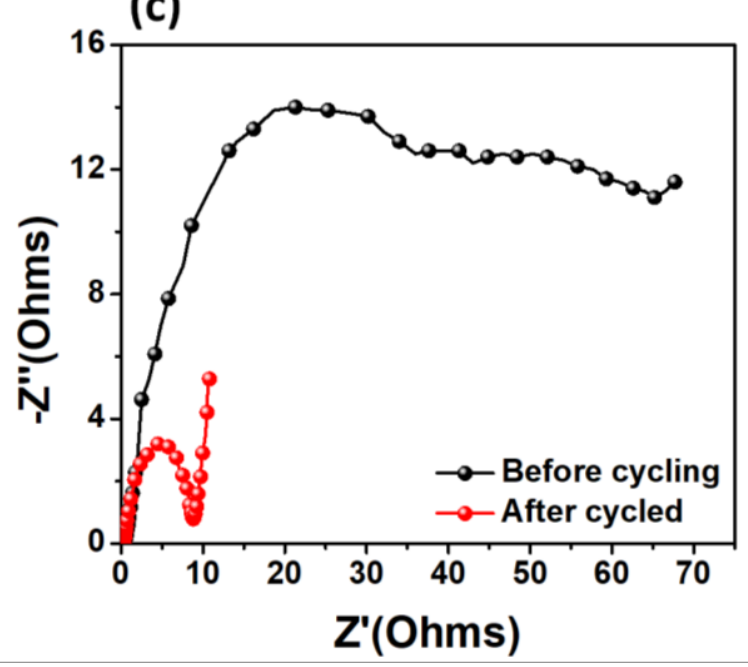

(d)
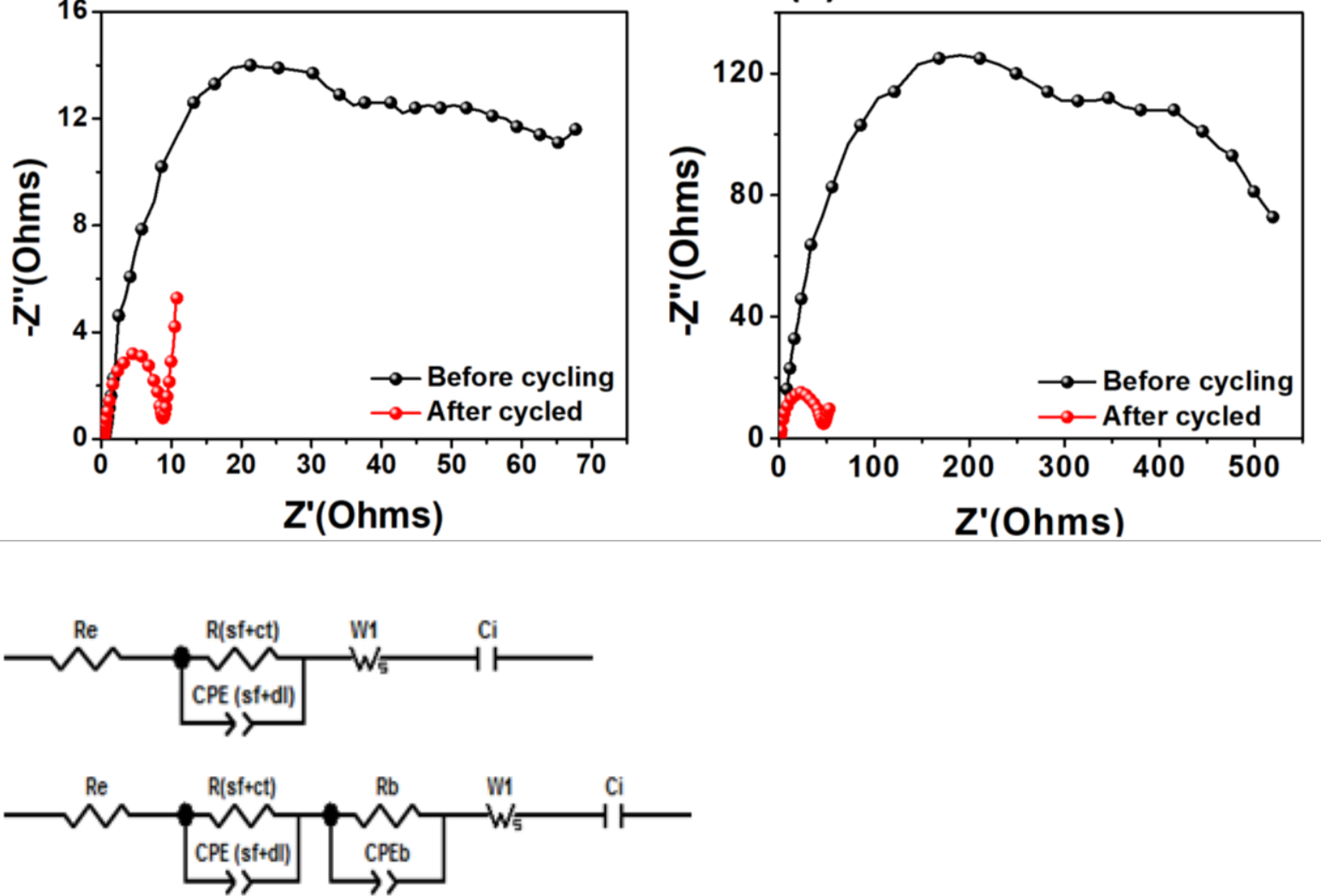
Table S1. The calculated theoretical capacities of PDI-Bz and PDI-Ur and their electrogenerated species.

\begin{tabular}{|c|c|c|c|c|}
\hline $\begin{array}{c}\text { Eelectrogenerated } \\
\text { species }\end{array}$ & $\begin{array}{c}\text { PDI-Bz } \\
\left(\text { (PDI-Bz }^{2-}\right)\end{array}$ & PDI-Bz $^{4-}$ & $\begin{array}{c}\text { PDI-Ur } \\
\left.\text { (PDI-Ur }^{3-}\right)\end{array}$ & PDI-Ur $^{5-}$ \\
\hline $\begin{array}{c}\text { Theoretical } \\
\text { capacity } \\
\left(\text { C }_{\text {theor, } \text { mAhg }}{ }^{-1}\right)\end{array}$ & 99 & 197.7 & 186 & 310 \\
\hline
\end{tabular}

Table S2. Comparison of the performance of PDI-Bz and PDI-Ur (vs Li+/Li \& $\mathrm{Na}^{+} / \mathrm{Na}$ ) with the-state-of-the-art PDI-based materials reported in the literature.

\begin{tabular}{|c|c|c|c|c|c|c|}
\hline Structure & $\begin{array}{c}\mathrm{C}_{\text {theor }} \\
\left(\mathrm{mAhg}^{-1}\right)\end{array}$ & Electrolyte & $\begin{array}{c}\text { Capacity } \\
\left(\text { mAhg }{ }^{-1}\right), \\
\text { current }\end{array}$ & $\begin{array}{c}\text { Potential: } \\
\text { oxidation/ } \\
\text { reduction (V), } \\
\text { reference }\end{array}$ & $\begin{array}{l}\text { Cycling } \\
\text { stability: } \\
\text { retention, } \\
\text { cycles, } \\
\text { current }\end{array}$ & Ref \\
\hline & 113 & $\begin{array}{l}1 \text { M LiPF6 } \\
\text { EC:DMC:EM } \\
\text { C } 1: 1: 1(\mathrm{v} / \mathrm{v} / \mathrm{v})\end{array}$ & $\mathbf{7 5 , 0 . 1 \mathrm { C }}$ & $\sim 2.33 \mathrm{~V}, \mathrm{Li}^{+} / \mathrm{Li}$ & $\begin{array}{l}92 \%, \\
0.1 \mathrm{C}\end{array}$ & 1 \\
\hline & 96.4 & $\begin{array}{lrr}1 & \text { M } & \text { LiPF6 } \\
\text { EC:DMC } & 1: 1 \\
\text { (v/v) } & \end{array}$ & $\begin{array}{ll}\mathbf{7 5 . 9}, & 0.05 \\
\mathrm{C} & \end{array}$ & $\begin{array}{l}\sim 2.5 \mathrm{~V}, \\
\mathrm{Li}^{+} / \mathrm{Li}\end{array}$ & $\begin{array}{l}80.2 \% . \\
500,2 \mathrm{C}\end{array}$ & 2 \\
\hline & 37 & $\begin{array}{l}1 \text { M LiPF6, } \\
\text { EC/DMC } \\
(1 / 1 \mathrm{v} / \mathrm{v})\end{array}$ & $27,0.05 \mathrm{C}$ & $\begin{array}{l}2.0 \quad(1.8 \& \& \\
2.3) \mathrm{V}, \mathrm{Li}^{+} / \mathrm{Li}\end{array}$ & $\begin{array}{l}99.97 \%, \\
300,0.05 \mathrm{C}\end{array}$ & 3 \\
\hline & 126 & $\begin{array}{l}1 \text { M LiTFSI, } \\
\text { DOL:DME } \\
(1 / 1 \mathrm{v} / \mathrm{v}) \\
1 \% \mathrm{LiNO}_{3}\end{array}$ & $116,0.33 \mathrm{C}$ & $\sim 2.4 \mathrm{~V}, \mathrm{Li}^{+} / \mathrm{Li}$ & $\begin{array}{l}70.9 \%, 99, \\
82.4 \mathrm{~mA} \mathrm{~g}^{-} \\
1\end{array}$ & 4 \\
\hline & 138 & $\begin{array}{l}1 \mathrm{M} \mathrm{Na} \mathrm{SO}_{4}: \\
0.1 \mathrm{M} \mathrm{HClO}_{4}\end{array}$ & $\mathbf{4 0}, 100 \mathrm{C}$ & $\begin{array}{l}\sim 0.48 \mathrm{~V}, \\
\mathrm{Na}^{+} / \mathrm{Na}\end{array}$ & $\begin{array}{l}85 \%, \quad 800, \\
100 \mathrm{C}\end{array}$ & 5 \\
\hline & 103 & $\begin{array}{l}1 \text { M LiPF6, } \\
\text { EC:DMC } \\
(1: 1 \mathrm{v} / \mathrm{v})\end{array}$ & $\begin{array}{ll}\mathbf{1 0 2}, & 17 \\
\mathrm{mAg}^{-1} & \end{array}$ & $\begin{array}{l}2.0 \& 2.25 \mathrm{~V} \\
\mathrm{Li}^{+} / \mathrm{Li} .\end{array}$ & $\begin{array}{l}86 \%, 1000, \\
200 \mathrm{~mA} \mathrm{~g}^{-1}\end{array}$ & 6 \\
\hline & 135 & $\begin{array}{l}1 \\
\mathrm{LiN}\left(\mathrm{CF}_{3} \mathrm{SO}_{2}\right) \\
\mathrm{DOL}: \mathrm{DME} \\
(2: 1 \mathrm{w} / \mathrm{w})\end{array}$ & $\begin{array}{ll}\mathbf{1 2 8 . 4}, & 50 \\
\mathrm{mAg}^{-1} & \end{array}$ & $\sim 1.1 \mathrm{~V}, \mathrm{Li}^{+} / \mathrm{Li}$ & $\begin{array}{l}90 \%, \quad 280, \\
200 \mathrm{~mA} \mathrm{~g}^{-1}\end{array}$ & 7 \\
\hline
\end{tabular}




\begin{tabular}{|c|c|c|c|c|c|c|}
\hline & 86 & $1 \mathrm{M} \mathrm{NaPF}_{6} \mathrm{PC}$ & $78, C / 4$ & $\sim 2.0 \mathrm{~V}, \mathrm{Na}^{+} / \mathrm{Na}$ & $\begin{array}{l}93 \%, \quad 20, \\
\mathrm{C} / 8\end{array}$ & 8 \\
\hline & 99 & $\begin{array}{l}1 \mathrm{M} \mathrm{LiPF} 6 \\
\text { EC:DMC }(1: 1 \\
\text { v/v) \& } \\
1 \mathrm{M} \quad \mathrm{NaClO}_{4} \\
\text { EC:DMC }(1: 1 \\
\text { v/v) }\end{array}$ & $\begin{array}{l}\mathbf{1 2 0} \text { (vs. } \\
\left.\mathrm{Li}^{+} / \mathrm{Li}\right) \& \text { \& } \\
\mathbf{1 1 1} \text { (vs. } \\
\mathrm{Na}^{+} / \mathrm{Na}^{2}, \\
25 \mathrm{mAg}^{-1}\end{array}$ & $\begin{array}{l}\sim 1.84 \mathrm{~V}, \mathrm{Li}^{+} / \mathrm{Li} \\
\& \sim 1.95 \mathrm{~V}, \\
\mathrm{Na}^{+} / \mathrm{Na}\end{array}$ & $\begin{array}{l}61 \% \\
\left(\mathrm{Li}^{+} / \mathrm{Li}\right), 10, \\
200 \mathrm{~mA} \mathrm{~g}^{-1} \\
\& \quad 3 \% \\
\left(\mathrm{Na}^{+} / \mathrm{Na}\right) \\
10,200 \mathrm{~mA} \\
\mathrm{~g}^{-1}\end{array}$ & $\begin{array}{l}\text { This } \\
\text { work }\end{array}$ \\
\hline PDI-Ur & 124 & $\begin{array}{ll}1^{1} \mathrm{MiPF}_{6} & \\
\mathrm{EC}: \mathrm{DMC}^{2} & (1: 1 \\
\mathrm{v} / \mathrm{v}) \quad \& \quad & 1 \mathrm{M} \\
\mathrm{NaClO}_{4} & \\
\mathrm{EC}: \mathrm{DMC}^{2} & (1: 1 \\
\mathrm{v} / \mathrm{v}) & \end{array}$ & $\begin{array}{l}119 \text { (vs. } \\
\left.\mathrm{Li}^{+} / \mathrm{Li}\right) \& \text { \& } \\
\mathbf{1 1 9} \text { (vs. } \\
\mathrm{Na}^{+} / \mathrm{Na}^{2}, \\
25 \mathrm{mAg}{ }^{-1}\end{array}$ & $\begin{array}{l}\sim 2.1 \mathrm{~V}, \mathrm{Li}^{+} / \mathrm{Li} \\
\& \quad \sim 2.1 \mathrm{~V}, \\
\mathrm{Na}^{+} / \mathrm{Na}\end{array}$ & $\begin{array}{l}99.9 \% \\
\left(\mathrm{Li}^{+} / \mathrm{Li}\right), \\
10,200 \mathrm{~mA} \\
\mathrm{~g}^{-1} \& 88 \% \\
\left(\mathrm{Na}^{+} / \mathrm{Na}\right) \\
10,200 \mathrm{~mA} \\
\mathrm{~g}^{-1}\end{array}$ & $\begin{array}{l}\text { This } \\
\text { work }\end{array}$ \\
\hline
\end{tabular}

\section{References}

(1) Iordache, A.; Delhorbe, V.; Bardet, M.; Dubois, L.; Gutel, T.; Picard, L. Perylene-Based All-Organic Redox Battery with Excellent Cycling Stability. ACS Appl. Mater. Interfaces, 2016, 8, 22762-22767.

(2) Schon, T. B.; Tilley, A. J.; Kynaston, E. L.; Seferos, D. S. Three-Dimensional Arylene Diimide Frameworks for Highly Stable Lithium Ion Batteries. ACS Appl. Mater. Interfaces, 2017, 9, 15631-15637.

(3) Wu, Y.-L.; Horwitz, N. E.; Chen, K.-S.; Gomez-Gualdron, D. A.; Luu, N. S.; Ma, L.; Wang, T. C.; Hersam, M. C.; Hupp, J. T.; Farha, O. K.; Snurr, R. Q.; Wasielewski, M. R. GQuadruplex Organic Frameworks, Nat. Chem., 2016, 9, 466-472.

(4) Xie, J.; Chen, W.; Wang, Z.; Jie, K. C. W.; Liu, M.; Zhang, Q. Synthesis and Exploration of Ladder-Structured Large Aromatic Dianhydrides as Organic Cathodes for Rechargeable Lithium-Ion Batteries, Chem. Asian J., 2017, 12, 868-876.

(5) Hernández, G.; Casado, N.; Zamarayeva, A. M.; Duey, J. K.; Armand, M.; Arias, A. C.; Mecerreyes, D. Perylene Polyimide-Polyether Anodes for Aqueous All-Organic Polymer Batteries, ACS Appl. Energy Mater., 2018, 1, 7199-7205.

(6) Veerababu, M.; Kothandaraman, R. Rational Functionalization of Perylene Diimide for Stable Capacity and Long-term Cycling Performance for Li-Ion Batteries, Electrochimica Acta 2017, 232, 244-253.

(7) Jung, M.-H.; Ghorpade, R. V.; Polyimide Containing Tricarbonyl Moiety as an Active Cathode for Rechargeable Li-Ion Batteries, J. Electrochem. Soc., 2018, 165, A2476-A2482.

(8) Banda, H.; Damien, D.; Nagarajan, K.; Raj, A.; Hariharan, M.; Shaijumon, M. M. Twisted Perylene Diimides with Tunable Redox Properties for Organic Sodium-Ion Batteries. Adv. Energy Mater., 2017, 1701316. 